ているが，これはインプラントの上のクラウンと隣接大 日崡偰作された，クラウンとが連続されているためで はないかと思う。インプラントに直接圧が加わる状態で の実験を是非お願いしたい。

応 答 中 島 知 範 (口 病)

インプラント単独で直接咬合圧を受け止めてくれるの が理想ではあるが，臨床では単独には使われていない． 実験は臨床に従って行なっているが，とくにての実験は 機能的範囲内で，最小限に近いと考えられる咬合圧を加 えた場合を一つの基準としたものである。

\section{9. 口蓋残孔について}

。神原 淳・池尼 茂 (2口外)

口蓋残孔に関する研究報告は，少なからず見受けられ るが，系統的なものは見られず，多くの解決されるべき 問題が残されている．我々は口蓋残孔の及ぼす種々な影 響のうち, とくに発音機能への影響を重視して, 本研究 に着手した。

今回は泼顎口蓋裂患者の形成手術後の口蓋残孔 6 例に つて, 語音発語明膫度検査（語明度）, 語音発語了解 度検查 (語了度)，および㭔気の鼻腔漏出気量検査を， 処置前，処置後に行ない，その差を残孔の影響と考え， その結果を報告した。

6 例中残孔の位置が口腔前庭䨑槽部に限局していた 2 例では, 語明度および語了度とも，0〜9\%の值で, 測 定語差範囲内之思われ，鼻腔漏出気量は $0 \%$ で, 残孔の 影響は認め難かった。. 残る 4 例は, 残孔が硬口蓋部に位 置しておう，各検查成績においてかなりの数值が認めら れた。. 552 例は，残孔の形態，大きさが類似してお り, 各検查成䋶もほぼ同様の数值が垫められた，他の 2 例中 1 例は硬口蓋前方部より㐘槽部使名る残孔を有し ており，その大きさは他の 3 例と同程度であったが，鼻 腔漏出気量は 4 例中最大で $28 \sim 41 \%$ であった，残る 1 例 は硬口蓋後方部に位置する残孔例で，その大きさも最大 （硬口蓋面積の $28.4 \%$ ）であったが，各検查成績は 4 例 中最も低い数值を示し, 鼻腔漏出気量は $5 \sim 7 \%$ あっっ た。 その理由として，残孔の一部が軟口蓋に及んでいた ため，閉鎖処置として装着されたプロテーゼの適合が完 全ではなかったてとが指摘された。

以上の結果を総括すれば，口蓋残孔が硬口蓋部に位置 する場合には，語明度において12〜 48\%，鼻腔漏出気量 において20〜40\%の影響が認められた。すなおち，硬口 蓋部での残孔の大きさが，一定度をこせば，その存在下 では, 開放性鼻音の発生が考えられ, accetable speech
の獲得は，かなり困難なものであると思われた。

\section{0. 市販インレーワックスの動的粘弾性について}

。井上勝一郎・林一郎・柿川宏 杉野恭彦・山田茂正（歯理工）

市販インレーワックスの物理的性質を理解すること は，精密な鋳造体を作製するために重要なととである。 今回われわれは, 市販インレーワックス 6 種類（直接法 ワックス 3 種類, 間接法ワックス 3 種類) について動的 粘弾性測定を行ない，それらのレオロジルな挙動につ いて検討した．測定周波数は110サイクル/秒とした。 そ の結果つぎのような結論を得た。

1. 本実験に使用したインレーワックスの動的弾性率

( $\left.\mathrm{E}^{\prime}\right)$ は $37^{\circ} \mathrm{C}$ で1.90〜2.09 x $10^{7} \mathrm{dyne} / \mathrm{ch}$ で, 直接法 ワックスの弹性率が間接法ワックスの值に比べてわず か比高い(Table 1).

2. 直接法ワックスでは $45^{\circ} \mathrm{C}$, 間接法ワックスは $37^{\circ} \mathrm{C}$ 付近から型の低下がみられる。

3. 非熱処理試料では, $40 \sim 50^{\circ} \mathrm{C}$ に損失弾性率 $\left(\mathrm{E}^{\prime \prime}\right)$ の著しい分散を生ずる。したがって，ワックスパター ン作製時には，かなりの残留ストレスが䝪えられるも のと思われる。

\begin{tabular}{|c|c|c|}
\hline Material & $\mathrm{E}^{\prime}\left(37^{\circ} \mathrm{C}\right) \mathrm{dyne} / \mathrm{cm}^{2}$ & Technique \\
\hline A & $1.92^{\left(\times 10^{7}\right)}$ & \\
\hline B & 2.09 & Direct \\
\hline $\mathrm{C}$ & 2.03 & \\
\hline $\mathrm{D}$ & 1.90 & \\
\hline $\mathrm{E}$ & 1.98 & Indirect \\
\hline $\mathrm{F}$ & 1.94 & \\
\hline
\end{tabular}

\section{1. 北九州地区における油症認定患者の口腔牾查につい} $\tau$

中山種秋・大森忠雄・村上守良 。六反田篤・深水康宽・清本和之（解 剖）

カネミ油症患者は，全身の皮膚に色素沈着が みられ る、私達は，口腔内に扔いて色素沈着の影響がみられる か, 北九州市, 田川市在住の 1 才〜 74才までの 132名（ 男性51名, 女性81名）について, 色素沈着状沉（特に煩 側歯肉）を調べた。

1. 色素沈着所有者は, 男性 $64.7 \%$, 女性 $71.6 \%$ で非 